\title{
POLA SPASIAL TEMPORAL KECELAKAAN LALU LINTAS DI DAERAH ISTIMEWA YOGYAKARTA
}

\author{
Saduddin \\ Pusat Studi Transportasi dan Logistik UGM \\ Jln. Kemuning M-3 Sekip \\ Sleman, Daerah Istimewa Yogyakarta 55284 \\ Tlp. (0274) 556928, 563984, 6491075 \\ saduddin@ugm.ac.id \\ Jan Prabowo Harmanto \\ Pusat Studi Transportasi dan Logistik UGM \\ Jalan Kemuning M-3 Sekip \\ Sleman, Daerah Istimewa Yogyakarta 55284 \\ Tlp. (0274) 556928, 563984, 6491075 \\ januarpraha@ugm.ac.id
}

\author{
Dewanti \\ Magister Sistem dan Teknik Transportasi \\ Departemen Teknik Sipil UGM \\ Jln. Grafika No. 2, Sleman 55281 \\ Tlp. (0274) 524712, 524713 \\ dewanti@mstt.ugm.ac.id \\ Hendra Edi Gunawan \\ Pusat Studi Transportasi dan Logistik UGM \\ Jalan Kemuning M-3 Sekip \\ Sleman, Daerah Istimewa Yogyakarta 55284 \\ Tlp. (0274) 556928, 563984, 6491075 \\ hendra_edi@ugm.ac.id
}

\begin{abstract}
This study aims to determine the area of traffic accident prone (hotspots) and determine the temporal spatial development of traffic accident areas in the Special Region of Yogyakarta, from 2016 to 2018. The method used is Optimized Hotspot Analysis and Directional Distribution with the help of ArcGIS software. The results of this study indicate that the location of traffic accidents in the Special Region of Yogyakarta is spread throughout the Special Region of Yogyakarta, with hotspots in 2016 located in 114 villages, in 2017 located in 110 villages, and in 2018 in 112 villages. The temporal spatial development of traffic accident locations in the Special Region of Yogyakarta changed from 2016 to 2018, with rotation in 2016 of 102.32 degrees, in 2017 of 37.59 degrees, and in 2018 of 45.55 degrees.
\end{abstract}

Keywords: traffic accidents, traffic accident locations, traffic accident prone areas, hotspots

\begin{abstract}
Abstrak
Penelitian ini bertujuan untuk menentukan daerah rawan kecelakaan lalu lintas (hotspots) dan menentukan perkembangan spasial temporal daerah kecelakaan lalu lintas di Daerah Istimewa Yogyakarta, dari tahun 2016 hingga tahun 2018. Metode yang digunakan adalah Optimized Hotspot Analysis dan Directional Distribution dengan bantuan perangkat lunak ArcGIS. Hasil penelitian ini menunjukkan bahwa lokasi kecelakaan lalu lintas di Daerah Istimewa Yogyakarta menyebar di seluruh wilayah Daerah Istimewa Yogyakarta, dengan wilayah hotspots tahun 2016 berada di 114 desa/kelurahan, tahun 2017 di 110 desa/kelurahan, dan tahun 2018 di 112 desa/kelurahan. Perkembangan spasial temporal lokasi kecelakaan lalu lintas di Daerah Istimewa Yogyakarta berubah dari tahun 2016 hingga tahun 2018, dengan rotasi di tahun 2016 sebesar 102,32 derajat, di tahun 2017 sebesar 37,59 derajat, dan di tahun 2018 sebesar 45,55 derajat.
\end{abstract}

Kata-kata kunci: kecelakaan lalu lintas, lokasi kecelakaan lalu lintas, daerah rawan kecelakaan lalu lintas, hotspots

\section{PENDAHULUAN}

Sistem transportasi jaringan jalan merupakan infrastuktur yang penting dan memiliki peran yang vital untuk aktivitas manusia. Oleh karena itu, diperlukan perencanaan dan manajemen yang efektif untuk menangani jaringan jalan. 
Suatu aspek sistem transportasi jaringan yang perlu diperhatikan adalah keselamatan jalan. Meningkatnya kematian dan kecelakaan lalu lintas di jalan dapat disebabkan oleh kecenderungan penggunaan kendaraan bermotor yang tidak tepat dan pengembangan infrastruktur jalan yang tidak memadai (Effati, 2012).

Jumlah korban jiwa dan kecelakaan lalu lintas di jalan sebagian besar dipengaruhi oleh 3 faktor, yaitu jalan, manusia, dan kendaraan. Saat ini, penanganan lokasi rawan kecelakaan lalu lintas, termasuk definisi, identifikasi, dan prioritas modifikasi telah menarik perhatian dan digunakan sebagai pendekatan untuk memperbaiki tingkat keselamatan lalu lintas di jalan (Aghajani et al., 2017).

Menurut laporan Bappeda Provinsi Daerah Istimewa Yogyakarta (2019), dalam kurun 5 tahun terakhir, jumlah kecelakaan lalu lintas di jalan telah mengalami peningkatan sebesar 45\% dengan jumlah kecelakaan lalu lintas pada tahun 2018 sebanyak 5.061 kasus. Meningkatnya jumlah kecelakaan lalu lintas ini berdampak pada jumlah korban meninggal dunia yang meningkat sebesar 53\% dari tahun 2014. Jumlah total korban meninggal dunia akibat kecelakaan lalu lintas di Provinsi Daerah Istimewa Yogyakarta adalah sebesar 2.102 jiwa dalam 5 tahun terakhir. Sedangkan korban luka berat mengalami penurunan hampir 3 kali lipat dari tahun 2014, namun jumlah korban luka ringan meningkat sebesar 35\%. Penelitian ini bertujuan untuk menentukan wilayah hotspot lokasi kecelakaan lalu lintas tahun 2016 hingga tahun 2018, dan mengkaji perkembangan spasial temporal daerah hotspot kecelakaan lalu lintas tersebut.

\section{METODE PENELITIAN}

Di tingkat makro, wilayah studi adalah di Provinsi Daerah Istimewa Yogyakarta, dengan data kecelakaan lalu lintas tahun 2016, tahun 2017, dan tahun 2018. Ada 2 metode yang dilakukan dalam penelitian ini, yaitu dengan melakukan analisis hotspot lokasi kecelakaan lalu lintas dengan Optimized Hotspot Analysis dan Direction Distribution data lokasi kecelakaan lalu lintas, seperti yang terlihat pada Tabel 1.

Tabel 1 Matriks Metode Penelitian

\begin{tabular}{|c|c|c|c|}
\hline No. & Tujuan & Metode & Keluaran \\
\hline 1 & $\begin{array}{l}\text { Menentukan wilayah hotspot daerah } \\
\text { rawan kecelakaan lalu lintas tahun } \\
\text { 2016-2018. }\end{array}$ & $\begin{array}{l}\text { Optimized Hotspot } \\
\text { Analysis }\end{array}$ & $\begin{array}{l}\text { Daerah rawan kecelakaan lalu } \\
\text { lintas tahun 2016-2018. }\end{array}$ \\
\hline 2 & $\begin{array}{l}\text { Mengkaji perkembangan spasial } \\
\text { temporal daerah kecelakaan lalu } \\
\text { lintas untuk tahun 2016-2018. }\end{array}$ & Directional Distribution & $\begin{array}{l}\text { Perkembangan spasial } \\
\text { temporal daerah rawan } \\
\text { kecelakaan lalu lintas tahun } \\
\text { 2016-2018. }\end{array}$ \\
\hline
\end{tabular}

Dalam optimized hotspot analysis, ditentukan titik kejadian atau fitur tertimbang (titik atau poligon), dan dibuat peta titik panas (hotspot) dan titik dingin (cold spot) yang 
signifikan secara statistika menggunakan statistik Getis-OrdGi *. Hal ini dimaksudkan untuk mengevaluasi karakteristik kelas fitur input untuk menghasilkan hasil yang optimal, seperti yang dapat dilihat pada Gambar 1.

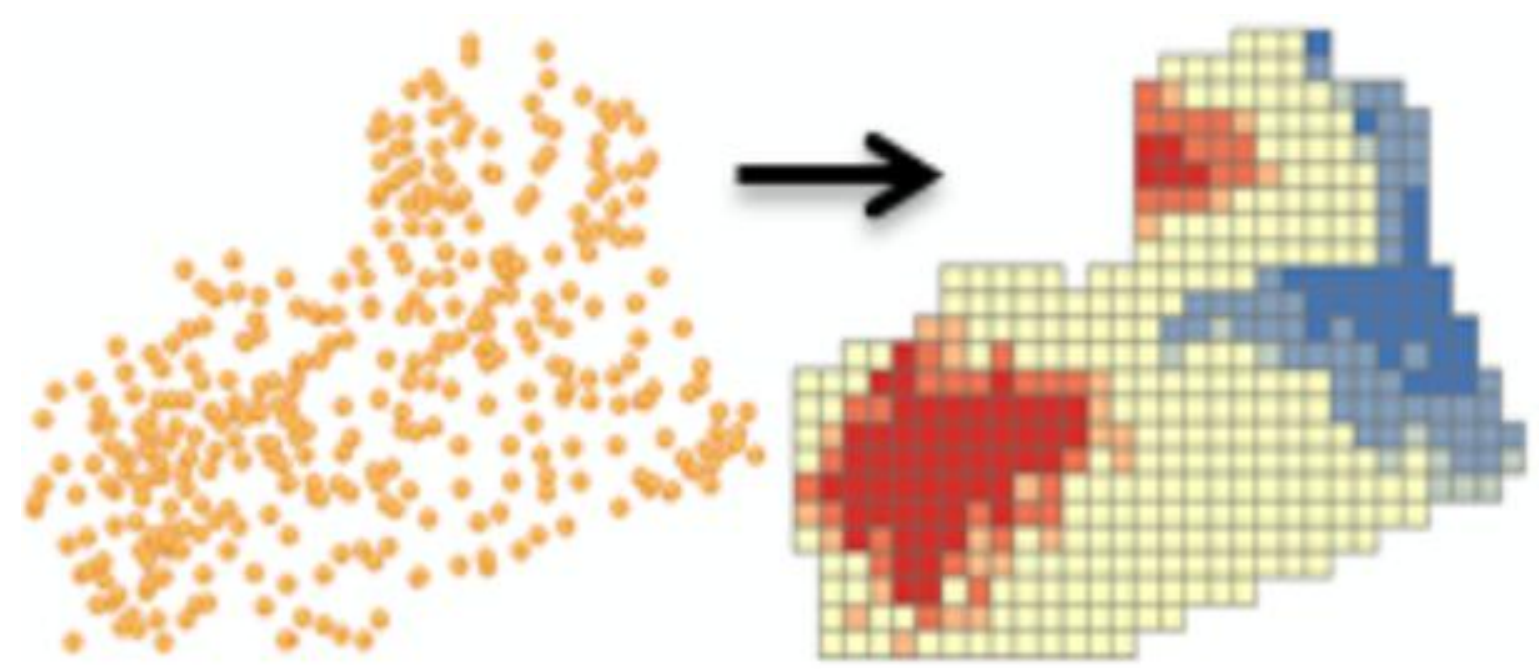

Gambar 1 Ilustrasi Analisis Hotspot

Hotspot menunjukkan konsentrasi kecelakaan lalu lintas di titik atau di area kecil, dan analisisnya menghitung statistik Getis-OrdGi, dengan fungsi Getis-OrdGi untuk semua fitur dalam data. Z-Score yang dihitung menunjukkan lokasi kluster kecil dan besar. Dalam menghasilkan hotspot yang diinginkan dari semua acara, pemetaan kluster berdasarkan pada fungsi kerapatan Getis-OrdGi dan Kernel:

$$
G i^{*}(d)=\frac{\sum_{j} W_{i j}(d) x_{j}-W_{i}^{*} \bar{x}^{*}}{s^{*}\left\{\left[\left(n s^{*} 1 i\right)-W_{i}^{* 2}\right] /(n-1)\right\}^{0.5}}
$$

dengan:

$\mathrm{W}_{\mathrm{ij}}(\mathrm{d})=$ vektor bobot spasial dengan nilai untuk semua sel 'j' dalam jarak d dari sel target i;

$W W 8 *=$ jumlah bobot;

$S S * 1 G G=$ jumlah bobot kuadrat; dan

$\mathrm{S} * \quad=$ deviasi standar data dalam sel (Ord dan Getis, 1995).

Direction distribution atau Ellipse Deviational Standard, digunakan untuk untuk meringkas karakteristik spasial fitur geografis, yaitu kecenderungan sentral, dispersi, dan tren arah. Ilustrasi tentang hal ini dapat dilihat pada Gambar 2.

Tahapan penelitian ini dapat dilihat pada Gambar 3. Dua hasil yang diharapkan adalah daerah rawan kecelakaan lalu lintas dan perkembangan secara spasial dan temporal daerah rawan kecelakaan lalu lintas tersebut pada tahun 2016 hingga tahun 2018. 


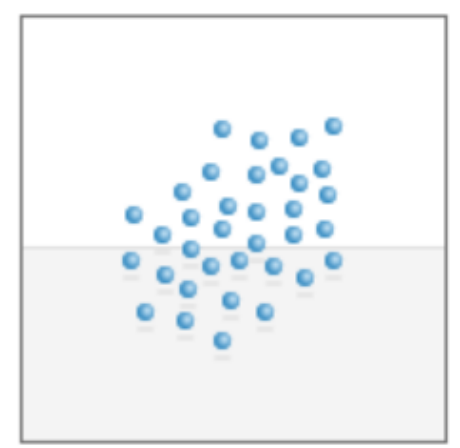

Input

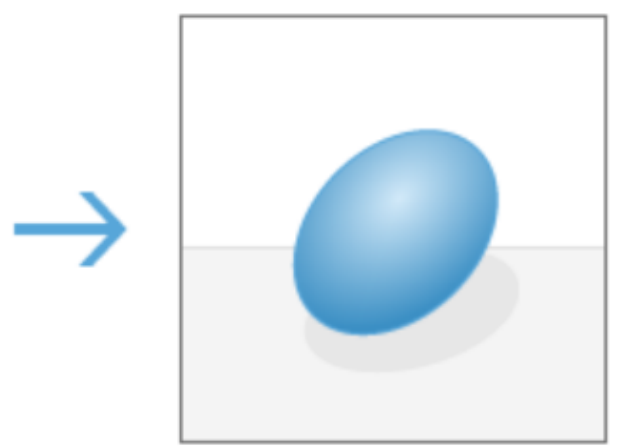

Output

Gambar 2 Ilustrasi Directional Distribution

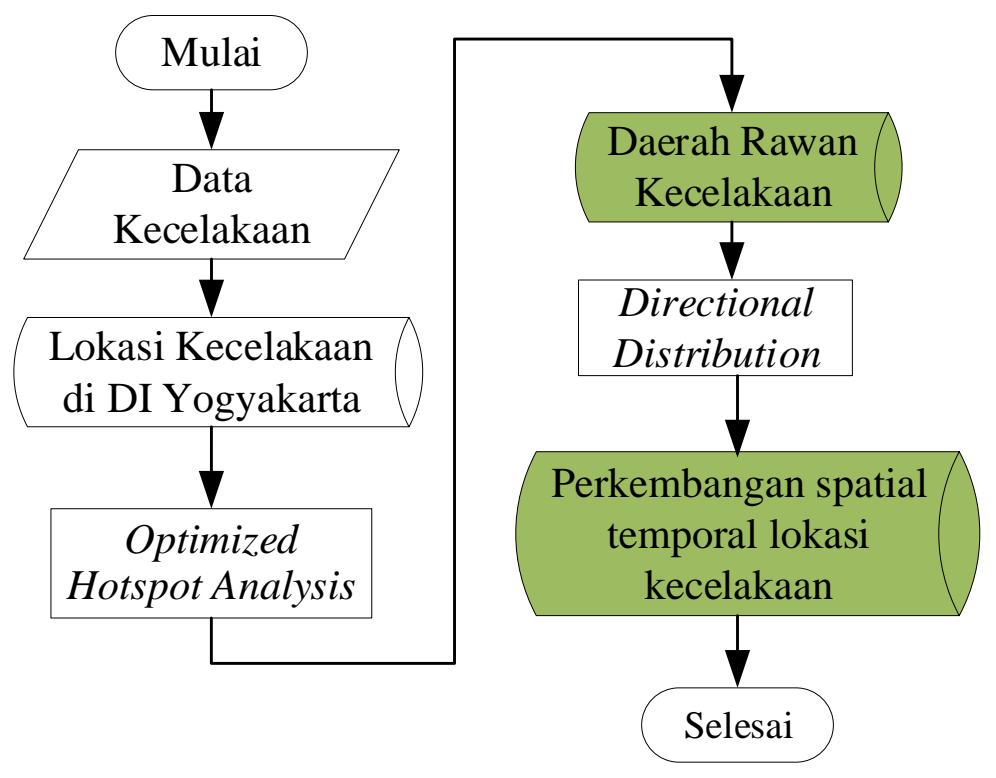

Gambar 3 Diagram Alir Penelitian

\section{HASIL DAN PEMBAHASAN}

Berdasarkan data yang diperoleh dari Ditlantas Polda Daerah Istimewa Yogyakarta, kejadian kecelakaan lalu lintas di Daerah Istimewa Yogyakarta dari tahun 2016 hingga tahun 2018 seperti yang terdapat pada Tabel 2. Jumlah kecelakaan lalu lintas pada tahun 2016 sebanyak 3.814 kejadian, dan terjadi peningkatan di tahun 2017, menjadi 4.226 kejadian. Pada tahun 2018 terjadi penurunan, sehingga menjadi 3.875 kejadian.

Data yang ada menunjukkan bahwa lokasi kecelakaan lalu lintas di Daerah Istimewa Yogyakarta menyebar di seluruh wilayah Daerah Istimewa Yogyakarta. Wilayah hotspot di tahun 2016, di tahun 2017, dan di tahun 2018 berturut-turut berada di 114 desa/kelurahan, $110 \mathrm{desa} /$ kelurahan, 112 desa/kelurahan. 
Tabel 2 Kecelakaan Lalu Lintas di Daerah Istimewa Yogyakarta 2016-2018

\begin{tabular}{|c|c|c|c|c|c|}
\hline \multirow[b]{2}{*}{ Wilayah } & \multicolumn{5}{|c|}{2016} \\
\hline & $\begin{array}{c}\text { Jumlah } \\
\text { Kecelakaan } \\
\text { Lalu Lintas }\end{array}$ & Kematian & $\begin{array}{l}\text { Cedera } \\
\text { Serius }\end{array}$ & $\begin{array}{l}\text { Cedera } \\
\text { Ringan }\end{array}$ & $\begin{array}{l}\text { Kerugian Material } \\
\qquad(\mathrm{Rp})\end{array}$ \\
\hline Yogyakarta & 618 & 57 & 0 & 825 & $582.600 .000,00$ \\
\hline Bantul & 1.183 & 155 & 0 & 1.251 & $496.105 .000,00$ \\
\hline Kulon Progo & 500 & 69 & 1 & 979 & $113.408 .000,00$ \\
\hline Gunungkidul & 492 & 75 & 2 & 607 & $144.750 .000,00$ \\
\hline Sleman & 1.021 & 190 & 9 & 1.229 & $893.975 .000,00$ \\
\hline Jumlah Total & 3.814 & 546 & 12 & 4.891 & $2.230 .838 .000,00$ \\
\hline \multirow[b]{2}{*}{ Wilayah } & \multicolumn{5}{|c|}{2017} \\
\hline & $\begin{array}{c}\text { Jumlah } \\
\text { Kecelakaan } \\
\text { Lalu Lintas } \\
\end{array}$ & Kematian & $\begin{array}{l}\text { Cedera } \\
\text { Serius }\end{array}$ & $\begin{array}{l}\text { Cedera } \\
\text { Ringan }\end{array}$ & $\begin{array}{l}\text { Kerugian Material } \\
\qquad(\mathrm{Rp})\end{array}$ \\
\hline Yogyakarta & 396 & 28 & 8 & 508 & $357.900 .040,00$ \\
\hline Bantul & 1.421 & 150 & 0 & 1.660 & $621.100 .000,00$ \\
\hline Kulon Progo & 411 & 68 & 11 & 775 & $99.200 .000,00$ \\
\hline Gunungkidul & 462 & 89 & 1 & 559 & $215.700 .000,00$ \\
\hline Sleman & 1.536 & 191 & 3 & 1.843 & $1.220 .410 .500,00$ \\
\hline Jumlah Total & 4.226 & 526 & 23 & 5.345 & $2.514 .310 .540,00$ \\
\hline \multirow[b]{2}{*}{ Wilayah } & \multicolumn{5}{|c|}{2018} \\
\hline & $\begin{array}{c}\text { Jumlah } \\
\text { Kecelakaan } \\
\text { Lalu Lintas }\end{array}$ & Kematian & $\begin{array}{l}\text { Cedera } \\
\text { Serius }\end{array}$ & $\begin{array}{l}\text { Cedera } \\
\text { Ringan }\end{array}$ & $\begin{array}{l}\text { Kerugian Material } \\
\qquad(\mathrm{Rp})\end{array}$ \\
\hline Yogyakarta & 359 & 19 & 6 & 525 & $265.475 .000,00$ \\
\hline Bantul & 1.353 & 123 & 0 & 1.994 & $569.955 .000,00$ \\
\hline Kulon Progo & 375 & 52 & 5 & 687 & $228.260 .000,00$ \\
\hline Gunungkidul & 422 & 82 & 1 & 489 & $222.310 .000,00$ \\
\hline Sleman & 1.366 & 157 & 2 & 1.762 & $877.925 .000,00$ \\
\hline Jumlah Total & 3.875 & 433 & 14 & 5.457 & $2.163 .925 .000,00$ \\
\hline
\end{tabular}

Tabel 3 Pertumbuhan Jumlah Kematian Akibat Kecelakaan Lalu Lintas di Daerah Istimewa Yogyakarta 2016-2018

\begin{tabular}{llrrr}
\hline Area & Deskripsi & 2016 & 2017 & 2018 \\
\hline Yogyakarta & Jumlah Kematian & 57 & 28 & 19 \\
& Pertumbuhan & & $-50,9 \%$ & $-32,1 \%$ \\
Bantul & Jumlah Kematian & 155 & 150 & 123 \\
& Pertumbuhan & & $-3,2 \%$ & $-18,0 \%$ \\
Kulon Progo & Jumlah Kematian & 69 & 68 & 52 \\
& Pertumbuhan & & $-1,4 \%$ & $-23,5 \%$ \\
Gunungkidul & Jumlah Kematian & 75 & 89 & 82 \\
& Pertumbuhan & & $18,7 \%$ & $-7,9 \%$ \\
Sleman & Jumlah Kematian & 190 & 191 & 157 \\
& Pertumbuhan & & $0,5 \%$ & $-17,8 \%$ \\
Daerah Istimewa & Jumlah Kematian & 546 & 526 & 433 \\
Yogyakarta & Pertumbuhan & & $-3,7 \%$ & $-17,7 \%$ \\
\hline Sumber: Ditlantas Polda Daerah Istimewa Yogyakarta & $(2018)$ &
\end{tabular}

Dilihat dari jumlah kematian akibat kecelakaan lalu lintas, pada tahun 2016 terjadi 546 kematian. Selanjutnya terjadi penurunan jumlah kematian, yang pada tahun 2017 terjadi 526 kematian, dan pada tahun 2018 terjadi 433 kematian. Kerugian material akibat kecelakaan lalu lintas yang terjadi di Daerah Istimewa Yogyakarta pada tahun 2016, tahun 
2017, dan tahun 2018 berturut-turut adalah Rp2.230.838.000,00, Rp2.514.310.540,00, dan Rp2.163.925.000,00.

Analisis hotspot menggunakan data vektor, bukan raster, untuk mengidentifikasi lokasi secara statistik tempat lokasi titik panas dan titik dingin yang signifikan, dalam bentuk data lokasi. Daerah hotspot kecelakaan lalu lintas di Daerah Istimewa Yogyakarta, untuk tahun 2016 hingga tahun 2018 dapat dilihat pada Gambar 4 hingga Gambar 6.

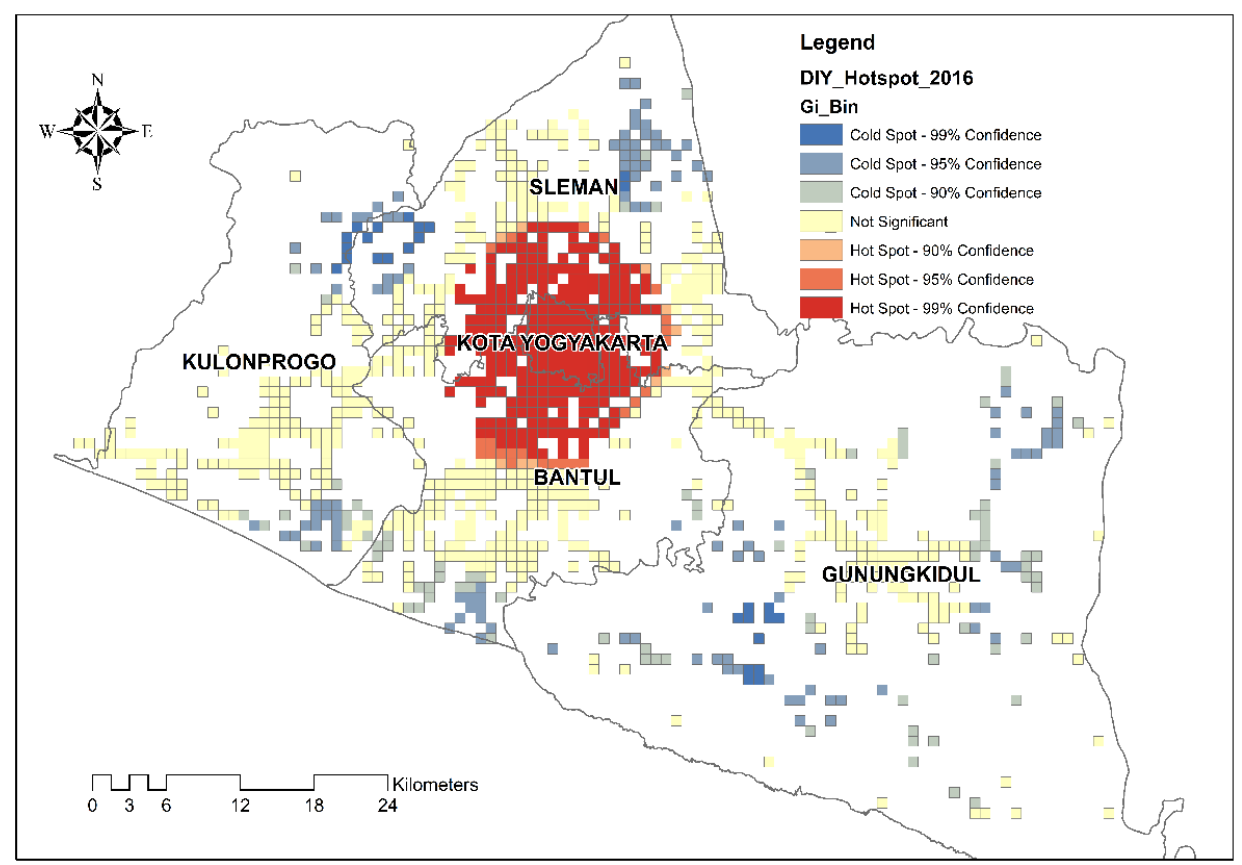

Gambar 4 Wilayah Hotspot Tahun 2016

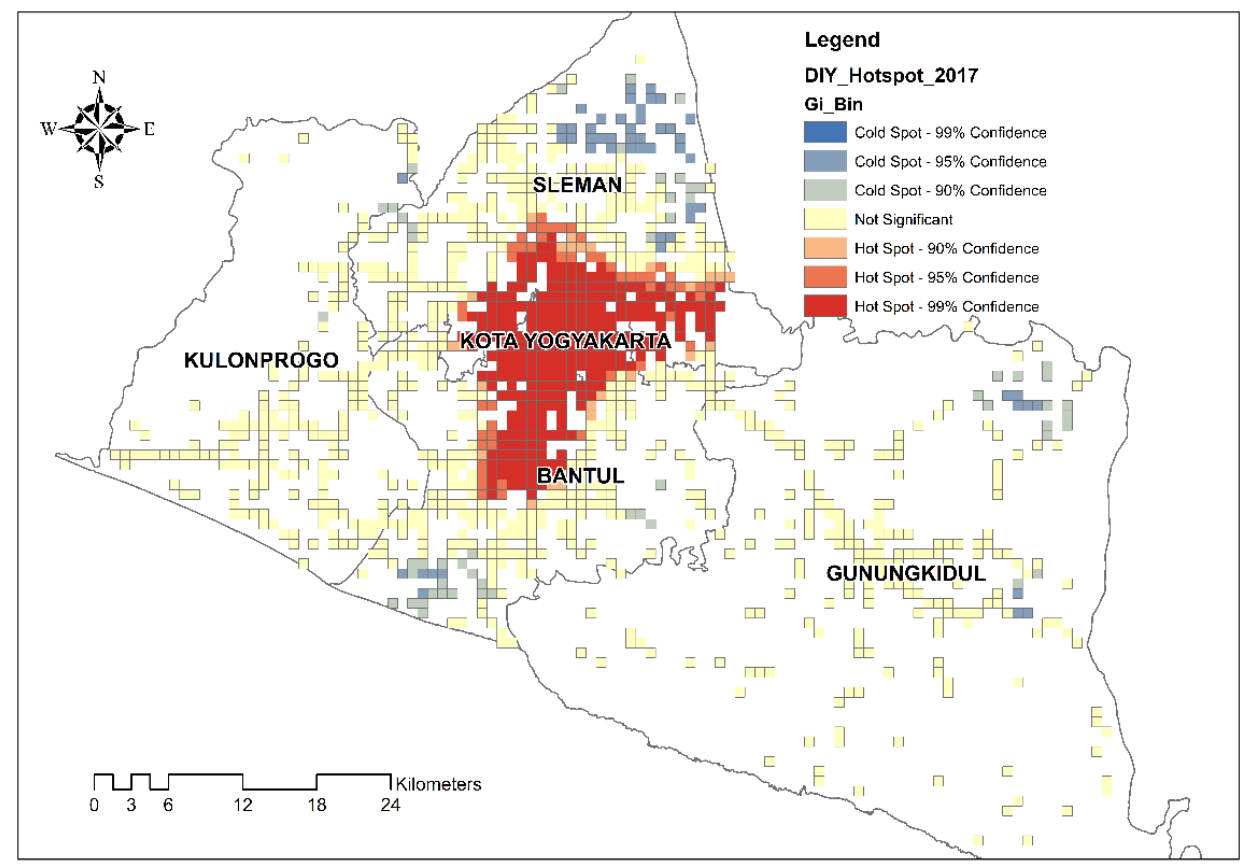

Gambar 5 Wilayah Hotspot Tahun 2017 


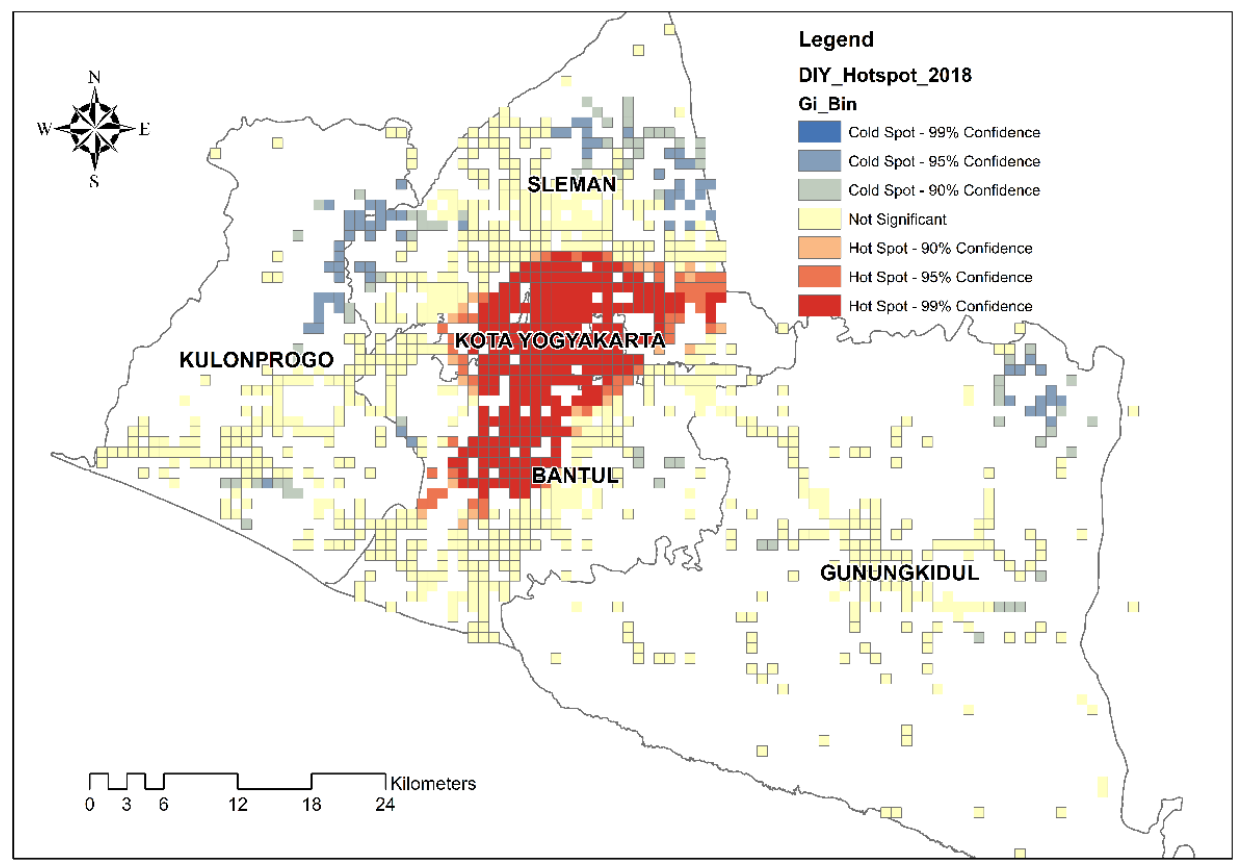

Gambar 6 Wilayah Hotspot Tahun 2018

Pada daerah kecelakaan lalu lintas 2016-2018, terjadi penurunan lokasi, dari 114 desa di tahun 2016 menjadi 112 desa di tahun 2018. Secara makro, mayoritas daerah kecelakaan lalu lintas berada di Kota Yogyakarta, Kabupaten Sleman, dan Bantul (lihat Tabel 2).

Tabel 2 Jumlah Daerah Rawan Kecelakaan Lalu Lintas

\begin{tabular}{ccccc}
\hline No. & Tahun & $\begin{array}{c}\text { Jumlah } \\
\text { Desa }\end{array}$ & $\begin{array}{c}\text { Jumlah } \\
\text { Kecamatan }\end{array}$ & $\begin{array}{c}\text { Jumlah } \\
\text { Kabupaten/Kota }\end{array}$ \\
\hline 1 & 2016 & 114 & 34 & 3 \\
2 & 2017 & 110 & 34 & 3 \\
3 & 2018 & 112 & 35 & 3 \\
\hline
\end{tabular}

Hasil analisis directional distribution menunjukkan bahwa terjadi pola spasial lokasi kecelakaan lalu lintas dari tahun 2016 ke 2017. Di tahun 2016, kecenderungan lokasi kecelakaan lalu lintas dengan rotasi 102,316 derajat berubah menjadi 37,590 derajat. Sedangkan pada tahun 2018 terjadi pergeseran dibandingkan tahun sebelumnya, menjadi 45,555 derajat (lihat Tabel 3).

Tabel 3 Hasil Analisis Directional Distribution

\begin{tabular}{ccccccc}
\hline No. & Tahun & Center $X$ & Center $Y$ & XStdDist & XStdDist & Rotation \\
\hline 1 & 2016 & 110,368 & $-7,839$ & 0,177 & 0,1169 & 102,316 \\
2 & 2017 & 110,375 & $-7,809$ & 0,052 & 0,0808 & 37,590 \\
3 & 2018 & 110,376 & $-7,816$ & 0,084 & 0,0485 & 45,555 \\
\hline
\end{tabular}

Secara gambar spasial, kecenderungan lokasi rawan kecelakaan lalu lintas di Daerah Istimewa Yogyakarta dapat dilihat pada Gambar 7 hingga Gambar 9. Terjadi perubahan lokasi kecelakaan lalu lintas dari tahun 2016 ke tahun 2017, sedangkan dari tahun 2017 ke tahun 2018 mempunyai kecenderungan lokasi yang sama. 


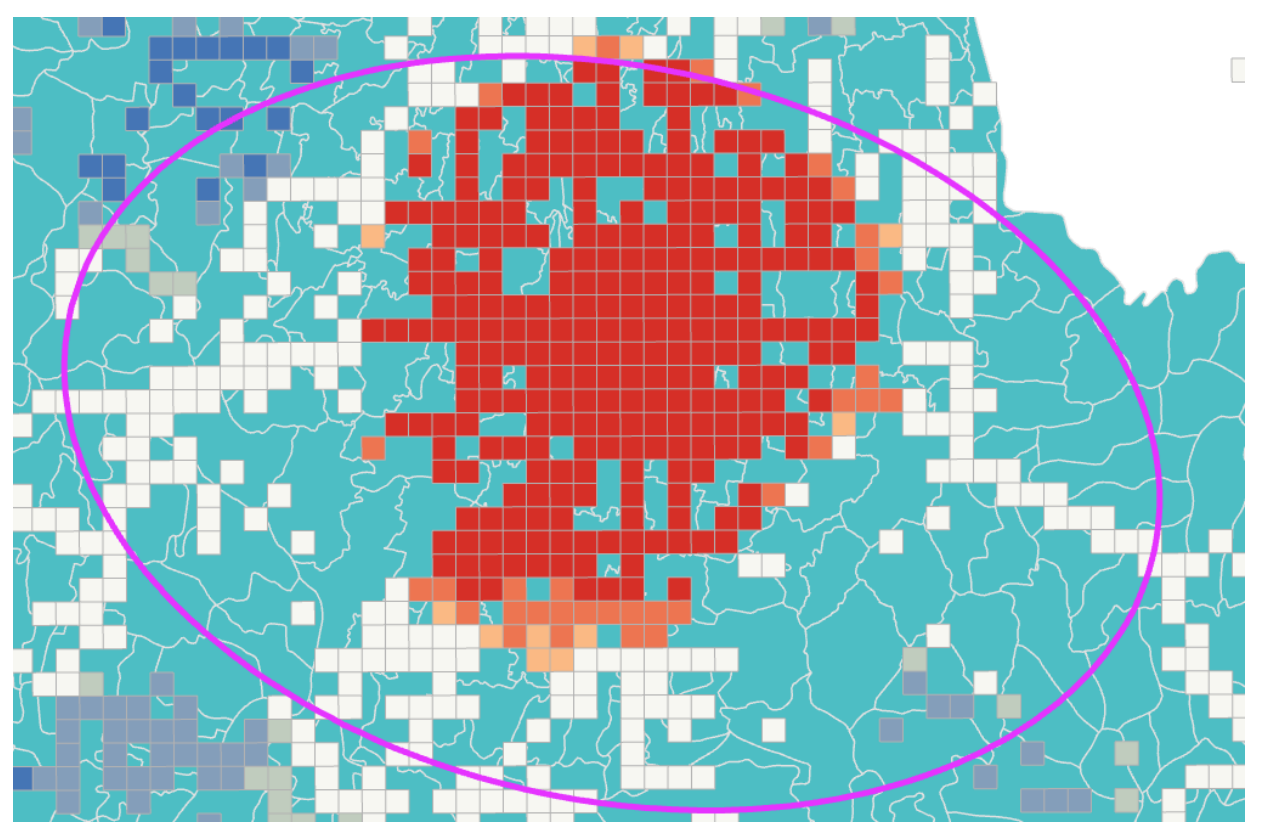

Gambar 7 Kecederungan Lokasi Kecelakaan Lalu Lintas Tahun 2016

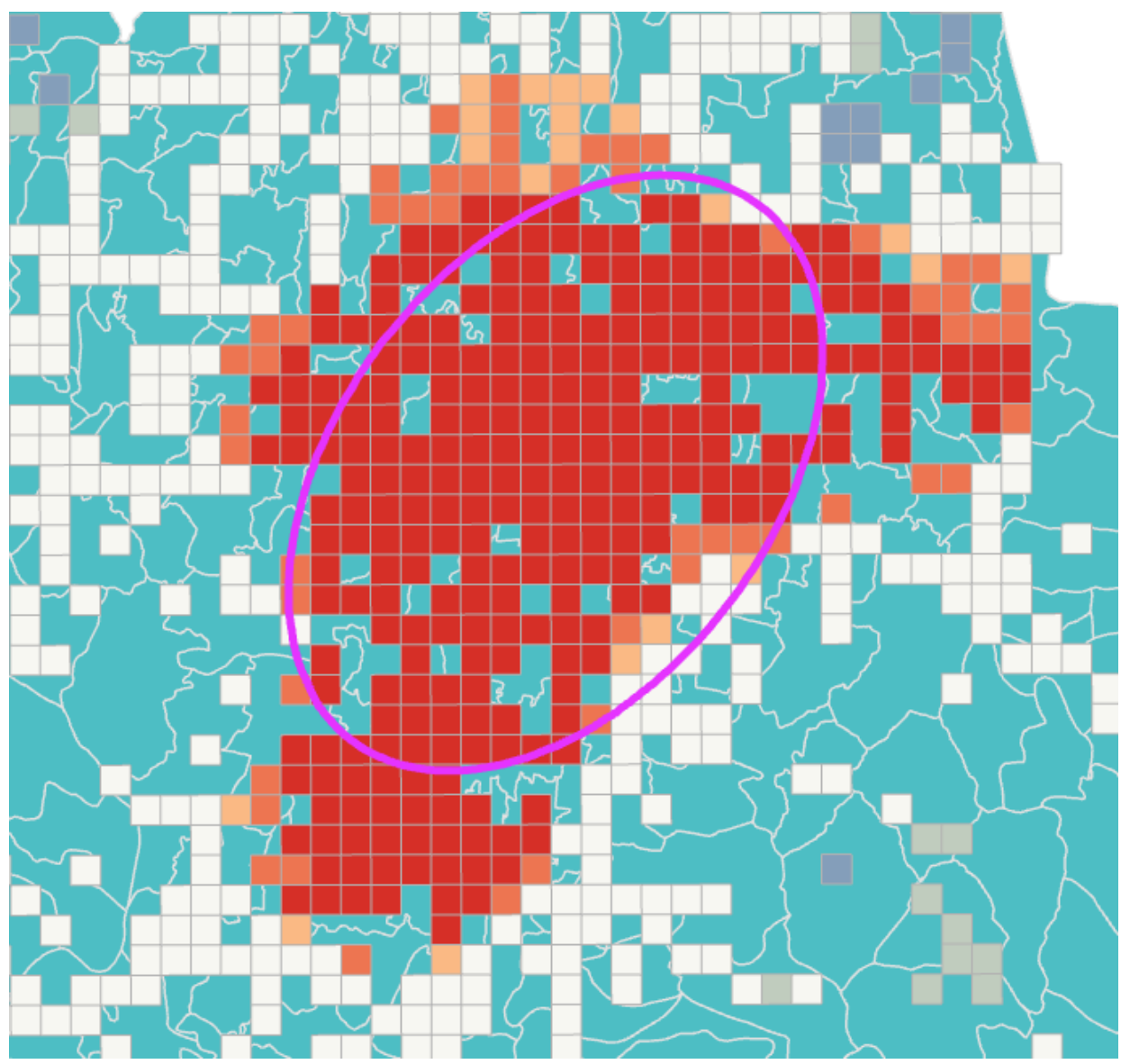

Gambar 8 Kecenderungan Lokasi Kecelakaan Lalu Lintas Tahun 2017 


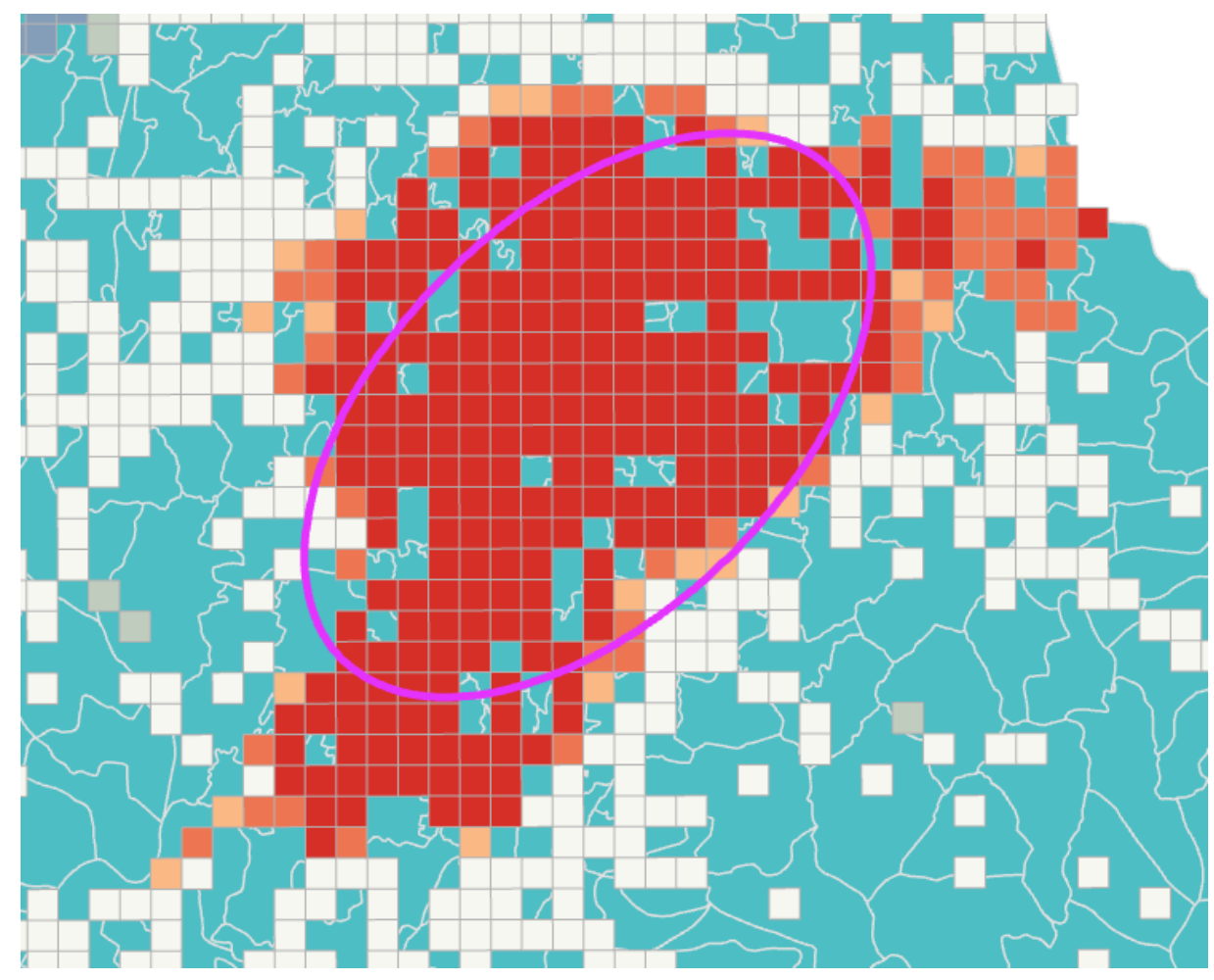

Gambar 9 Kecenderungan Lokasi Kecelakaan Lalu Lintas Tahun 2018

\section{KESIMPULAN}

Dari penelitian yang telah dilakukan ini dapat diambil kesimpulan sebagai berikut:

1) Lokasi kecelakaan lalu lintas di Daerah Istimewa Yogyakarta menyebar di seluruh wilayah Daerah Istimewa Yogyakarta, dengan wilayah hotspot pada tahun 2016 berada di 114 desa/kelurahan, pada tahun 2017 di 110 desa/kelurahan, dan pada tahun 2018 di 112 desa/kelurahan.

2) Perkembangan spasial temporal lokasi kecelakaan lalu lintas di Daerah Istimewa Yogyakarta berubah dari tahun 2016 ke tahun 2018 dengan rotasi di tahun 2016 sebesar 102,32 derajat, di tahun 2017 sebesar 37,59 derajat, dan di tahun 2018 sebesar 45,55 derajat.

\section{UCAPAN TERIMA KASIH}

Ucapan terima kasih disampaikan kepada Traffic Accident Research Center, Direktorat Keamanan dan Keselamatan KORLANTAS POLRI, Ditlantas Daerah Istimewa Yogyakarta, dan Pusat Studi Transportasi dan Logistik (Pustral) UGM atas dukungan data, sehingga penelitian ini dapat diselesaikan. Semoga hasil penelitian ini dapat bermanfaat bagi masyarakat yang membutuhkan serta bagi pihak-pihak lain yang membutuhkan informasi ini untuk penelitian lebih lanjut. 


\section{DAFTAR PUSTAKA}

Aghajani, M.A., Dezfoulian, R.S., Arjroody, A.R., dan Rezaei, M. 2017. Applying GIS to Identify the Spatial and Temporal Patterns of Road Accidents Using Spatial Statistics: Case Study Ilam Province, Iran. Transportation Research Procedia, 25: 21262138.

Badan Perencanaan Pembangunan Daerah Provinsi Daerah Istimewa Yogyakarta. 2019. Data Kecelakaan Lalu Lintas dan Pelanggaran Lalu Lintas: Data Vertikal Kepolisian Republik Indonesia Daerah. (Online), (http://bap-peda.jogjaprov.go.id/dataku/data_ dasar/index/548-data-kecelakaanlalulintas-danpelanggaran-lalu-lintas?id_skpd=39\#48 diakses 28 Agustus 2019).

Direktorat Lalu Lintas Polda Daerah Istimewa Yogyakarta. 2018. Data Kecelakaan Lalu Lintas Tahun 2016-2018. Tidak dipublikasikan. Yogyakarta: Ditlantas Polda Daerah Istimewa Yogyakarta.

Effati, M. 2012. Determining Roads Black Spots Using Spatial Information Systems and Multicriteria Decision Making Processes. Transportation Engineering, 4: 349-363.

Ord, J.K. dan Getis, A. 1995. Local Spatial Autocorrelation Statistics: Distributional Issues and an Application. Geographical Analysis, 27 (4): 287-306. 